\title{
The effectiveness of single minute exchange of dies for lean changeover process in printing industry
}

\author{
Sri Indrawati", Mentari Endah Pratiwi, Sunaryo, and Abdullah 'Azzam \\ Industrial Engineering, Universitas Islam Indonesia, Yogyakarta, Indonesia
}

\begin{abstract}
The changeover time is a factor that greatly affects the lean production implementation in industry with make to order system. Large product variations and unpredictable quantity of orders will trigger some kind of production wastes if changeover time is done in a longer time. One industry with make to order system is printing industry. In general, to produce several types of products such as books takes quite a long time because of long production changeover process. The general problem faced is the delay in book's production completion. Based on this problem, changeover time reduction is needed to overcome the delay of book's production completion using single minute exchanges of dies (SMED) method. The SMED method is the method that separates the changeover activity into two, i.e. internal setup and external setup. The research shows that changeover time for printing workstation is 18 minutes 29 seconds, which consists of internal setup activities 14 minutes 37 seconds and external setup 4 minutes 33 seconds. By converting $45 \%$ of the internal setup activity into an external setup, then the setup time can be reduced. The initial setup activities performed when machine is stop, now can be done when the machine is running. In addition, a changeover process improvement also done using $5 \mathrm{~S}$ method in workstation tools area so the internal setup time is reduced $46 \%$ becomes 7 minutes 59 seconds. Under these conditions, the printing industry can increase production by $2 \%$.
\end{abstract}

\section{Introduction}

The growth of industrial competition and customer demand are influencing every industry with a make-toorder system to improve production performance in fulfilling customer demand. Fast order completion time and short delivery time are key to today's industry competition [1]. If an industry does not increase the speed of production, then the industry cannot compete with other industries. Because customers will prefer industries that fulfil orders quickly.

To increase the speed of customer order fulfilment, the industry must analyse several factors that affect its productivity. Factors influencing the productivity of newspapers printing industry are changeover time, information flow, machine condition, quality, production rate and workers [2]. Changeover time and process time greatly affect the cycle time of producing a product. To improve the speed, every industry should be able to minimize the changeover and processing time, so that customer satisfaction will be achieved [3]. Changeover time is a preparation time for processing new lots or new products [4]. Changeover time can be reduced by using the single minute exchange of dies (SMED) method [5].

SMED implementation of critical components replacement in Extrusion machine can reduce replacement time by 19 minutes and 25 minutes for caster machine [6]. SMED also successfully applied with metal forming objects in the automotive industry to improve work processes so that production time can be reduced [7]. SMED implementation allows for changeover time reduction, through reorganization of the industry's internal resources without requiring significant investment [8].

By changeover time reduction, an industry can save production costs and increase sales by $2 \%$ [9]. The SMED method can be integrated with other methods such as Theory of Inventive Problem Solving (TRIZ). The integration of these two methods can reduce the changeover time from 240 minutes to 32 minutes in the intel technology production process [10].

The SMED method can be used to reduce non value added activity. A total of 75 internal set up and 2 idle activities can be identified through SMED implementation in injection mold machine [11]. SMED is implement in the automotive industry with the result of a $30 \%$ reduction in production cost and 97 seconds in production time [12]. The SMED method is one of lean tools that used to reduce production waste in current value stream map [13]. Using SMED method, activity that does not add value to the product can be reduced [14]. The reduction of some non-value added and non-necessary non value added activities can improve production efficiency [15].

One industry with make to order system is printing industry. This industry is mainly producing books, but there are also other products, i.e. calendars, invitation cards and notes. In general, the production process is done

* Corresponding author: sriindrawati@uii.ac.id 
according to the number of orders by customers. To fulfil the customer's order, it is required to complete orders based on customer specification. The problem faced is the delay in production completion that lead to delivery lateness. It is caused by a different changeover time of each workstation. For cutting \pm 5 minutes and printing \pm 18 minutes. Since a long changeover time appear in production, it will cut the available time for production. That will shorten production time, so production quantity will be less. In fact, to complete one order, sometimes it takes more than a day. With a long changeover time, it is necessary to make improvement so the production process can be completed on time by reducing changeover time. Changeover time consist of internal setup and external setup. Reducing changeover time can be done using SMED method.

\section{Basic Theory}

Single minutes exchange of dies (SMED) is one of improvement methods for lean manufacturing implementation. In lean manufacturing, all production wastes are being eliminated through a systematic approach [15]. Changeover time is one form of waste in the lean concept that must be eliminated because it is not provide an added value to customers and result in inefficient process. The SMED method can be used to reduce changeover time. This method can be implemented for all types of industries and all types of machines [16]. Single minute does not mean that setup time takes only one minute, but takes under 10 minutes or single digit minute [17].

The setup time is defined as a certain time to prepare production process and system required in production [18]. In setup time there are organizational time such as machine stoppage and maintenance, equipment setup, machine set up, changeover and startup, adjustment and production trials. Changeover time is the time to prepare production process with new type of product or lot size as seen in Figure 1[4].

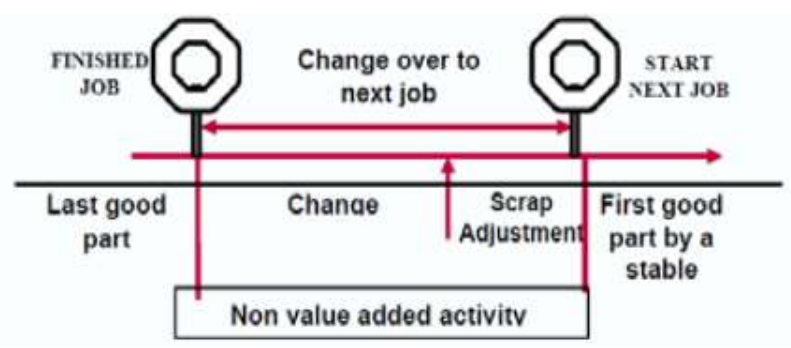

Fig 1. Changeover process [19] Changeover time should be reduced so the production process will be more efficient.

There are four major stages in SMED method, i.e. [20]:

a. The documentation process

The process of recording all setup activities is done in this stage. The setup activities consist of removal, installation of new equipment on machine and others. The documentation process can be done by recording all activities and time during the set up process using a stopwatch and recorded on a worksheet.

b. Identify internal and external activities
Determine all setup activities and identify the internal and external setup. Internal setup is an activity that should be done when machine stopped. External setup is an activity that can be done when the machine still producing parts.

c. Convert internal setup to external The main goal of reducing setup time is to reduce internal setup time. This process is done by analyzing each internal setup activity and determine the possibilities to convert it into external setup activity.

d. Reduced internal activity

This process is done by simplifying movement, reducing movement and elimination of movement. $50 \%$ of setup reduction usually determined as SMED implementation target for many industry [21].

\section{Research Framework}

This research is conducted at printing and publisher $\mathrm{AB}$ located in Yogyakarta, Indonesia. This printing and publishing industry is producing books, brochures, calendars, tabloids and invitation cards. Research begins by collecting data of production time, setup time, production cost, product types and production process. The data then being verified with statistics, i.e. sufficiency and uniformity data test. Then it is subsequently used to calculate cycle time, normal time and standard time to analyze the production process time. The SMED analysis is then performed by identifying setup activities and separating the internal and external setup activities. Identification of several factors affecting the production setup activities is done to find out some potential internal setup activities that can be eliminated. Simplification of movement and lean improvement of changeover process is done based on the results of previous process evaluation. Further, a comparative analysis of initial and final production quantity is done to determine the effectiveness of SMED implementation in lean changeover process.

\section{Discussion}

There are four workstations used in the book production process, i.e. printing, cutting, drafting and bending. The standard time of the book production process on each workstation is measured using time study method. Based on statistical testing, the data already sufficient and uniform. The largest standard time is on printing workstation, $83,88 \mathrm{sec}$./ unit with production capability of 300 units/ day. For production process on cutting and drafting workstation have no significant standard time difference that is equal to 74,2 and 75,47 sec./ unit with production capability equal to 339 and 334 units/ day. While bending time is the smallest that is equal to 47,18 sec./ unit with a largest production capability of 534 units/ day.

Potential production bottleneck is printing workstation with largest standard time. So production activities in printing workstation needs to be analyzed by SMED method. Observations on changeover process in printing workstation is done to classify internal and 
external setup elements. The internal setup element is an activity that can only be done when the machine stops, while external elements can be performed while machine is working. The results of changeover process documentation and its classification indicates that there are 41 types of book production changeover activities consisting of $75,6 \%$ internal setup 838,2 seconds or 14 minutes 37 seconds and 24,4\% external setup 259,36 seconds or 4 minutes 33 seconds.

Further, some activities are changed from internal setup to external setup. Setup is done when the machine is off, can be done when the machine is working. When the machine produces previous product, the operator can prepare for the next product, so changeover time becomes shorter. Because there are no specific reference for converting internal activity to external activity, then the conversion is done based on industry condition. To reduce delays, the operator should do some setup activity to produce the next product while the machine still proceed the previous product. There are also several activities performed in parallel, so two jobs can be done simultaneously such as when the operator runs the paper, the also take the paper plate. There are $45 \%$ of internal activity transformed into external activity. The remaining 17 internal activities still exist with 460,11 seconds or 8 minutes 7 seconds.

Based on potential cause analysis of high intenal setup time, there are several factors that influence, i.e. the number of equipment is less so that operators have to wait each other to use a certain equipment. In addition there is no certain place used for placing the production tools so that operators need to find a tool because the tool does not have a permanent place. Therefore, it is necessary to improve toolbox using the principles of 5S (Seiri, Seiton, Seiso, Seiketsu, Shitsuke), so the time wasted for activity searching and tidying tools can be eliminated. The lean changeover process based on SMED and 5S is developed as seen in Appendix 1. The original internal setup time is 838,2 seconds or 14 minutes 37 seconds. By improving changeover process, the new internal setup time is 455,55 seconds or 7 minutes 59 seconds.

The effectiveness of changeover process improvement that has been done using the SMED method is measured using production quantity parameter. The initial production capability in printing workstation is 300 units/ day whereas after improving the changeover process becomes 306 units/ day. There is an increase in book production and revenues of $2 \%$ per day.

\section{Conclussion}

Based on the research that has been conducted, the production activity of printing workstation becomes the biggest potential bottleneck in printing industry. Proven with the largest standard time among other workstation activities. The changeover time for the printing workstation is 1097,56 seconds or 18 minutes 29 seconds, which consists of 838,2 seconds or 14 minutes 37 seconds for internal setup activities and an external setup of 4,32 minutes. After improving the changeover process using SMED method and $5 \mathrm{~S}$ principle, the internal setup time is reduced $46 \%$ becomes 455,55 seconds or 7 minutes 59 seconds. It can increase production quantity by $2 \%$ per day.

Researchers thank to the support of Industrial Engineering Department, Faculty of Industrial Technology, Universitas Islam Indonesia.

\section{References}

1. Shtub, A. \& Cohen, Y., Introduction to Industrial Engineering 2nd Edition, CRC Press, USA, (2016)

2. Ifra Research, Optimising Productivity in Newspaper, Production Lines, Ifra Special Report 3.33: 01-23, (2001)

3. Esa, M.M., Rahman, N.A.A., Jamaludin, M., Reducing High Setup Time in Assembly Line: A Case Study of Automotive Manufacturing Company in Malaysia, Procedia Social and Behavioral Science, Vol. 211: 215-220, (2015)

4. Bicheno, J. \& Holweg, M., The Lean Toolbox: The Essential Guide to Lean Transformation, Production and Inventory Control, System and Industrial Books, UK, (2009)

5. Mcintosh, R.I., Culley, S.J., Mileham, A.R. Owen, G.W., Improving Changeover Performance: A Strategy for Becoming a Lean, Responsive Manufacturer, Butterworth Heinemann, UK, (2001)

6. Nurtrianto, R., Analisis Dan Perancangan Sistem Informasi Penjadwalan Preventive Maintenance Pada PT Starmas Inti Aluminium Industry, Binus University, Jakarta, (2011)

7. Refrizal \& Sudarmadji, H., Aplikasi Metoda SMED Untuk Perbaikan Waktu Proses Ganti Model (Changeover Time) Dan Waktu Penyetelan (Setup Time), Jurnal Me Trik Polban, Vol. .5, No. 02, (2011)

8. Arvianto, A. \& Arista, R., Usulan Perbaikan Operation Point Sheet Pada Mesin Feeder Aida 1100 Dengan Menggunakan Metode SMED,J@Ti Undip, Vol VI, No 2: 125-136, (2011)

9. António, C.M \& Gil, C.S.P., Single Minute Exchange of Die A Case Study Implementation, Journal of Technology Management Innovation, Vol. 6, Issue 1: 130-146, (2011)

10. Kartik, S.K. \& Muhamad, Z.M.S, Integration of SMED and TRIZ in Improving Productivity at Semiconductor Industry, Jurnal Mekanikal. no 33: 40-55, (2011)

11. Novitasari, P.P., Arif, R., Ceria, F.M.T., Perbaikan Waktu Setup Dengan Pendekatan Single Minute Exchange of Dies (SMED) Untuk Mengurangi Unnecessary Motion Waste, Jurnal Rekayasa dan Manajemen Sistem Industri, Vol. 1. No. 1: 1-10. (2013)

12. Rahul, R. J. \& Naik, G.R., Application Of Smed Methodology- A Case Study In Small Scale Industry, International Journal of Scientific and Research Publications, Vol. 2, Issue 8: 2250-3153, (2012) 
13. Saputra, F. \& Widyadana, I.G.A., Penurunan Waste Proses Produksi Produk RJK Di Departemen DEW PT. X Dengan Value Stream Mapping, Jurnal Tirta, Vol 1. No.2 :233-240, (2013)

14. Abdul, W.N., Surachman., Nasir, W.S., \& Rudi, S., Implementasi Konsep Lean Manufacturing Untuk Meminimalkan Waktu Keterlambatan Penyelesaian Produk "A" Sebagai Value Pelanggan Studi Kasus PT TSW (Tuban Steel Work), Jurnal Rekayasa Mesin, Vol.4: 147-156, (2013)

15. Indrawati, S. \& Ridwansyah, M., Manufacturing Performance Improvement Through Lean Six Sigma Method: An Iron Ores Industry Case Application, Procedia Manufacturing, Vol 4: 528-534, (2015)

16. Shingo, S. A., Revolution in Manufacturing: The SMED System. Productivity Press, Cambridge, (1983)
17. Dave, Y. \& Sohani, N., Single Minute Exchange of Dies, Journal of Lean Thinking, Vol. 3, Issue 2: 2737, (2012)

18. Rother, M. \& Shook, J., Learning to See: Value Stream Mapping to Add Value and Eliminate MUDA, Lean Enterprise Institute Inc., USA, (2009)

19. Ulutas, B., An Application of SMED Methodology, World Academy of Science, Engineering and Technology, Vol 79: 100-103, (2011)

20. Raikar, N.A., Reduction in Setup Time by SMED Methodology: A Case Study, International Journal of Latest Trends in Engineering and Technology, Vol.5, Issue 4: 56-60, (2015)

21. Kusar, J., Berlec, T., Zefran, F., Starbek, M., Reduction of Machine Setup Time, Journal of Mechanical Engineering, Vol. 56, Issue 12: 833-845, (2010) 
Appendix 1. Lean Changeover Process for Printing Industry

\begin{tabular}{|c|c|c|c|c|}
\hline No & Activity & Time (s) & Internal & External \\
\hline 1 & Arranging the plate & 3,46 & & $\sqrt{ }$ \\
\hline 2 & Take a ruler and plate & 13,78 & & $\sqrt{ }$ \\
\hline 3 & Measure the plate & 59,52 & & $\sqrt{ }$ \\
\hline 4 & Preparing the paper & 116,09 & & $\sqrt{ }$ \\
\hline 5 & Loading paper & 61,28 & & $\sqrt{ }$ \\
\hline 6 & Set the paper position & 85,1 & $\sqrt{ }$ & \\
\hline 7 & Set the place of printed paper & 33,76 & $\sqrt{ }$ & \\
\hline 8 & Running paper & 52,02 & & $\sqrt{ }$ \\
\hline 9 & Take the paper & 13,78 & & $\sqrt{ }$ \\
\hline 10 & Take the plate & 32,96 & & $\sqrt{ }$ \\
\hline 11 & Take a screwdriver & 8,68 & $\sqrt{ }$ & \\
\hline 12 & Rotate the bolt & 73,15 & $\sqrt{ }$ & \\
\hline 13 & Returns the screwdriver & 2,66 & $\sqrt{ }$ & \\
\hline 14 & Placing the plate & 55,69 & $\sqrt{ }$ & \\
\hline 15 & Take a screwdriver & 6,54 & $\sqrt{ }$ & \\
\hline 16 & Rotate the bolt & 15,64 & $\sqrt{ }$ & \\
\hline 17 & Returns the screwdriver & 2,17 & $\sqrt{ }$ & \\
\hline 18 & Setting up ink & 25,59 & & $\sqrt{ }$ \\
\hline 19 & Cleaning plate and roller & 37,9 & $\sqrt{ }$ & \\
\hline 20 & Insert ink & 29,08 & $\sqrt{ }$ & \\
\hline 21 & Adjust the ink volume & 15,59 & $\sqrt{ }$ & \\
\hline 22 & Rotate the machine to flatten the ink & 46,26 & & $\sqrt{ }$ \\
\hline 23 & Try printing & 18,14 & & $\sqrt{ }$ \\
\hline 24 & Checking print results & 30,5 & & $\sqrt{ }$ \\
\hline 25 & Set the paper size & 31,23 & $\sqrt{ }$ & \\
\hline 26 & Giving lubricant & 35,53 & & $\sqrt{ }$ \\
\hline 27 & Set the ink & 5,6 & & $\sqrt{ }$ \\
\hline 28 & Try printing & 20,33 & & $\sqrt{ }$ \\
\hline 29 & Checking print results & 20,74 & & $\sqrt{ }$ \\
\hline 30 & Ensure the paper position & 43,67 & $\sqrt{ }$ & \\
\hline 31 & Try printing & 4,55 & & $\sqrt{ }$ \\
\hline 32 & Checking print results & 31,82 & & $\sqrt{ }$ \\
\hline 33 & Set the paper & 14,69 & $\sqrt{ }$ & \\
\hline 34 & Try printing & 9,58 & & $\sqrt{ }$ \\
\hline \multirow[t]{2}{*}{35} & Checking print results & 25,42 & & $\sqrt{ }$ \\
\hline & Total & 1082,5 & 455,55 & 626,95 \\
\hline
\end{tabular}

